\title{
Politik Birokrasi Hatta Rahman Pada Pilkada Serentak 2015 Di Kabupaten Maros
}

\author{
Muh. Irfan, Anggriani Alamsyah, Fajar \\ Program Studi Ilmu Politik UIN Alauddin Makassar
}

\begin{abstract}
Abstrak
Paper ini mendiskusikan tentang bentuk kekuatan politik birokrasi atas kemenangan incumbent Hatta Rahman pada Pilkada Serentak 2015 di Kabupaten Maros. Penelitian ini merupakan penelitian kualitatif dan menggunakan teori strategi politik dan teori birokrasi untuk memahami bagaimana kekuatan politik birokrasi bekerja di Maros. Hasil penelitian menunjukan bahwa salah satu strategi politik yang dilakukan incumbent untuk memenangkan kontestasi pemilu adalah dengan memanfaatkan kekuatan birokrasi. Posisi Hatta Rahman selaku calon incumbent dapat dengan mudah mempengaruhi dan memobilisasi dukungan politik dari kalangan birokrat. Selain itu, birokrasi menjadi media komunikasi yang efektif bagi incumbent untuk berkomunikasi dan memperoleh simpati dan dukungan politik dari masyarakat.
\end{abstract}

Kata Kunci :

Strategi Politik, Politik Birokrasi, Pilkada Serentak 2015

\section{PENDAHULUAN}

Pada masa Orde Baru, pemilihan umum (Pemilu) sebagai pesta politik 5 (lima) tahunan dibayangkan sebagai peragaan perbedaan yang tetap bertumpu pada kesatuan dan bermuara pada terjaganya kohesi sosial dalam tubuh masyarakat. Pada bulan Februari 1981, Soeharto menyebut pemilu sebagai "Pesta Demokrasi", sebuah konsep yang kemudian selalu didengung-dengungkan oleh aparat birokrasi negara. Cara pandang ini berusaha menciptakan gambaran bahwa tidak ada lagi perbedaan yang mengancam kesatuan negara. Dengan demikian, pemilu yang menentukan wakil-wakil rakyat dari berbagai aspirasi tidak lagi dipandang sebagai konflik tapi sebagai sebuah pesta Bhineka Tunggal Ika di bawah naungan negara. ${ }^{1}$

Dalam analisis Pemberton, representasi pemilu sebagai aksi ritual periodik dan pesta demokrasi tersebut hanyalah desain-desain yang dirancang secara top-down. Apabila pemilu yang didesain dari atas ini diterima oleh masyarakat, maka mereka tidak akan melakukan resistensi yang berarti dan dengan demikian praktek dominasi juga tidak perlu dilakukan oleh aparat negara. Jika ini terjadi, berarti pemerintah berhasil memahami

1 Alexander Irwan, Pemilu Pelanggaran Asas Luber, (Jakarta : Pustaka Sinar Harapan, 1996), h. 45. nilai-nilai, jalan-jalan pikiran, dan kepentingan kelompok-kelompok dalam masyarakat dan menemukan cara-cara komunikasi yang tepat untuk meyakinkan masing-masing kelompok bahwa kepentingan yang dikejar negara juga merupakan kepentingan mereka masing-masing. ${ }^{2}$

Setelah jatuhnya rezim Orde Baru, perubahan di ranah lokal sedang berlangsung. Format dan pola pemerintahan daerah termasuk pemilihan kepala daerah direvisi mengikut semangat reformasi yang tengah berlangsung di Indonesia. Hasilnya kelihatan dari terbitnya dua undang-undang pemerintahan daerah di waktu yang relatif berdekatan, yakni; UU No. 22 Tahun 1999 dan UU No. 32 Tahun 2004. Menurut Leo Agustino, dari banyak butir yang dituangkan dalam pasal dan ayat pada undang-undang yang disebutkan terakhir, salah satunya membahas pengisian posisi kepala daerah secara demokratis, dan prosedur itu di namakan pemilihan kepala daerah secara langsung (Pilkada) atau pemilihan umum kepala daerah (Pemilukada). ${ }^{3}$ Walaupun dikemudian hari, rezim Pilkada menjadi perdebatan apakah bagian dari rezim pemilihan umum (Pemilu) atau bukan.

\footnotetext{
${ }^{2}$ Alexander, h. 46.

3 Leo Agustino, Politik Lokal dan Otonomi Daerah, (Bandung:Alfabeta, 2014), h.130. Selanjutnya, yang digunakan adalah istilah Pilkada bukan Pemilukada walaupun menurut penulis tidak ada perbedaan di antara keduanya.
} 
Pilkada merupakan sebagian kecil dari pelaksanaan sekaligus proses demokrasi di ranah lokal. Karena mekanisme ini hanya memberi ruang partisipasi yang amat terbatas dalam proses demokrasi pada aspek pemberian suara semata. Sementara aspek demokrasi yang lebih luas terdapat pada skop politik keseharian (days to days politics) yang justru berlangsung pasca Pilkada sampai tiba pemilihan selanjutnya. Namun demikian, kita tidak dapat meremehkan peran Pilkada dalam proses pendalaman demokrasi di ranah lokal sebab dengan Pilkada masyarakat menentukan pemimpin daerah yang akan mewarnai kehidupan sosio-politik, sosio-kultur dan sosio-ekonomi daerah. ${ }^{4}$

Dalam konteks otonomi atau desentralisasi, tentu saja, Pilkada harus dimengerti dan dipahami sebagai fungsi dan penciptaan effective governance: ketatapemerintahan yang pelaksanaan peranannya sepenuhnya ditujukan pada penguatan kapasitas diri (pemerintah) dan masyarakatnya. Dalam bahasa umum effective governance ini dapat dipertukarkan dengan good local governance. ${ }^{5}$ Merujuk pada Joel Migdal, effective governance menyangkut kapabiltisas dan kapasitas negara (aparatur pemerintah) untuk melaksanakan penetrasi pada masyarakatnya, mengatur relasi sosial (social control), mengambil sumber daya (extracing) dan mengelola sumber daya (apporoproating). ${ }^{6}$ Pilkada langsung, mau tidak mau dalam konteks ini, menjadi instrumen penting dalam memfasilitasi warga untuk terlibat dalam negosiasi permanen mengenai; bagaimana dan dengan sumber daya apa politik lokal harus diatur, serta ke mana politik lokal harus dibawa. Artinya, warga negara berhak menyatakan pendapat mereka sendiri tentang apa yang mereka kehendaki, termasuk mengkritik para pejabat negara, rezim pemerintahan, tatanan sosial ekonomi, dan ideologi yang ada. ${ }^{7}$

Keterlibatan masyarakat secara langsung dalam proses pemilihan pemimpin daerah melalui mekanisme Pilkada merupakan wujud terdistribusinya kekuasaan ke tingkat lokal. Secara bersamaan, proses ini melahirkan kekuatankekuatan baru yang tampil dalam rupa "elit-elit

\footnotetext{
${ }^{4}$ Leo, h.131.

${ }^{5}$ Leo, h. 27.

${ }^{6}$ Joel Migdal, Strong Societies and Weak States: State Society Relation and State Capabilities in the Third World. (Princeton: Princeton University Press, 1988).

7 Cholisin \& Nasiwan, Dasar-Dasar Ilmu Politik (Yogyakarta: Penerbit Ombak, 2012), h. 135.
}

politik lokal" yang memainkan peran signifikan dalam berbagai kontestasi politik yang berlangsung di ranah lokal untuk memperoleh simpati dan dukungan dari masyarakat. Berbagai strategi politik akan dimainkan demi memenangkan kontestasi politik, mulai dari pertarungan wacana hingga pertarungan fisik. Salah satu strategi yang umum digunakan oleh para politisi untuk mempengaruhi persepsi dan preferensi politik masyarakat adalah dengan melalui strategi "kekuatan politik birokrasi". Di mana birokrasi dijadikan sebagai instrumen yang menguntungkan secara elektoral.

Pilkada tahun 2015 yang lalu menjadi momentum bagi menguatnya penggunaan kekuatan politik birokrasi oleh para politisi. Kabupaten Maros merupakan satu diantara sekian banyak daerah yang melangsungkan Pilkada Serentak di Indonesia, khususnya di Sulawesi Selatan. Beberapa daerah di di Sulawesi Selatan, seperti Bulukumba, Kepulauan Selayar, Gowa, Pangkajene dan Kepulauan, Tana Toraja, Luwu Utara, Toraja Utara, Barru, Soppeng, Luwu Timur dan Maros. Di Maros sendiri diikuti beberapa kandidat, yakni pasangan 1. Imran Yusuf \& Said Patombongi 2. Husain Rasul \& Andi Sudirman 3. Hatta Rahman \& Harmil Mattorang.

Dari penjelasan di atas, studi ini bermaksud untuk mengungkap bagaimana bentuk kekuatan politik birokrasi dalam mendukung kemenangan Hatta Rahman pada Pilkada Serentak 2015 di Kabupaten Maros.

\section{LITERATUR REVIEW}

Sepanjang penelusuran penulis, ada beberapa literatur yang berkaitan dengan penelitian ini. Di antaranya tulisan Dian Rhesa Rahmayanti. Rahmayanti menjelaskan proses pemasaran politik Partai Golkar dan Partai Demokrat dalam rangka menarik massa pada Pemilihan Umum Legislatif tahun 2009 di Daerah Pemilihan II Kabupaten Madiun. Penelitian ini juga menjelaskan mediamedia pemasaran politik yang dilakukan kedua partai tersebut dan aplikasi secara nyatanya dilapangan. ${ }^{8}$ Hal serupa yang diteliti Hartini Basaria Natasya Sitanggang dan Awang

${ }^{8}$ Dian Rhesa Rahmayanti, "Pemasaran Politik (Political Marketing) Partai Golongan Karya Dan Partai Demokrat. (Studi Tentang Perbandingan Pemasaran Politik Partai Golkar Dan Partai Demokrat Dalam Rangka Menarik Massa Pada Pemilihan Umum Legislatif Tahun 2009 Di Daerah Pilihan II Kabupaten Madiun", Skripsi (Surakarta: Fakultas Ilmu Sosial dan Ilmu Politik Universitas Sebelas Maret Surakarta, 2009), h. xvi. 
Dharmawan. Sitanggang dan Dharmawan menjelaskan bagaimana kekuatan media baru sebagai sumber informasi politik dimanfaatkan oleh konsultan politik untuk mempromosikan partai politik atau kandidat perseorangan. Seperti halnya Hary Tanoesoedibjo dan partainya Partai Indonesia Raya (Perindo), sebagai salah satu pebisnis media yang juga meniti jalan di dunia politik, memanfaatkan media yang dimilikinya sebagai alat marketing politiknya untuk menampilkan citra dan program partainya adalah keniscayaan. $^{9}$

Sementara itu, Ajeng Niadharma dalam penelitiannya di Gresik tidak menjadikan media sebagai faktor determinan. Niadharma melihat bahwa strategi pemasaran politik pasangan Sambari - Qosim pada Pilkada Gresik sedikit banyak ditentukan oleh soliditas antar keduanya sebagai pasangan ideal yang tidak pecah kongsi dalam menghadapi Pilkada Gresik tahun 2015. ${ }^{10}$ Jika Niadharma melihat citra soliditas sebagai bagian dari maketing politik, lain halnya Umaimah Wahid yang menggunakan paradigma konstruktivisme dalam membaca marketing politik yang dipraktikkan. Berkaca pada kasus Pilkada Jakarta, Wahid memandang bahwa personal branding sangat penting dibentuk oleh komunikator politik khususnya politisi yang ikut Pilkada karena strategi ini mampu mengdongkrak popularitas dan kepercayaan publik. Mislanya, teks pidato pada agenda penentuan nomor urut nyatanya dipergunakan secara maksimal oleh calon kandidat terutama pasangan Agus Yudhoyono-Silviana Murni sebagai pasangan yang cenderung diragukan. Sekalipun kalah pada akhirnya, namun personal branding yang dibangun pasangan calon ini setidaknya mampu menepis keraguan publik atas kemampuannya. ${ }^{11}$

9 Hartini Basaria Natasya Sitanggang dan Awang Dharmawan, "Strategi Marketing Hary Tanoesoedibjo dalam Usaha Membangun Personal Branding Politik", Jurnal Penelitian Pers dan Komunikasi Pembangunan, Vol. 20 No.1 (Juni 2016), h. 49-62.

${ }^{10}$ Ajeng Niadharma, "Strategi Pemasaran Politik Pasangan Sambari-Qosim Dalam PemilihanKepala Daerah Gresik Tahun 2015", Jurnal Politik Muda,Vol. 5, Nomor 3, (AgustusDesember 2016), h. 369-374.

11 Umaimah Wahid "Personal Brandingdan Retorika Komunikator Politik Pada Pemilukada DKI Jakarta 2017 (Analisis Retorika Atas Teks Pidato Sebagai Kandidat Gubernur Dan Wakil Gubernur Pada Penentuan Nomor Urut Peserta Pemilu)", Prosiding Seminar Nasional : Komunikasi Publik dan Dinamika Masyarakat Lokal (Lampung: Magister Ilmu Komunikasi, Universitas Lampung, 2016).
Beragam marketing politik yang telah dijelaskan di atas, tulisan Ayub Liwang sedikit berbeda. Liwang membidik proses Pilkada Gowa tahun 2015 dan bagaimana Adnan Purichta - Karaeng Kio memenangkan kontestasi. Liwang menemukan bahwa kekuatan politik yang mendukung kemenangan Adnan - Kio adalah basis Klan Politik, Birokrasi dan Media Massa. Sekalipun pasangan calon ini lewat jalur independen, namun beberapa partai politik memberikan dukungan penuh. $^{12}$

Dari ulasan di atas dapat disimpulkan bahwa dalam proses elektoral dibutuhkan strategi politik yang memadai untuk memenangkan kontestasi, baik citra soliditas, kemampuan personal, penggunaan media, mesin partai, nama besar dan pengaruh klan politik maupun penggunaan kekuatan birokrasi. Lalu apa yang membedakan dengan penelitian penulis?. Sekalipun Liwang menyinggung keterlibatan birokrasi dalam proses kemenangan Adnan - Kio, akan tetapi bukan menjadi fokus dalam bangunan analisisnya. Olehnya itu, studi ini akan fokus melihat bagaimana kekuatan politik birokrasi bekerja dalam proses Pilkada yang sedang berlangsung di Kabupaten Maros tahun 2015.

\section{TINJAUAN TEORETIS}

\section{Strategi Politik}

Strategi politik merupakan strategi yang di gunakan untuk mewujudkan cita-cita politik. Contohnya adalah pemberlakuan peraturan baru, pembentukan suatu struktur baru dalam administrasi pemerintahan, atau dijalankanya tindakan deregulasi privatisasi atau desentralisasi. ${ }^{13}$ Sedangkan menurut Clausewit strategi adalah pengetahuan tentang penggunaan pertempuran untuk memenangkan peperangan. ${ }^{14}$ Bagi Firmanzah, srategis adalah sesuatu yang penting, baik dari segi sumber daya yang dikorbankan maupun efeknya pada organisasi secara keseluruhan. ${ }^{15}$

${ }^{12}$ Ayub Liwang, "Kekuatan dan Stretegi Politik Dalam Pemilukada, Analisis Kemenangan Adnan Puricta dalam Pilkada Kab. Gowa tahun 2015", Skripsi, (Makassar: Jurusan Ilmu Politik, Fakultas Ushuluddin, Filsafat dan Ilmu Politik, UIN Alauddin, 2015).

${ }_{13}$ Peter Schröder, Strategi Politik, Cet. Tiga (Jakarta: Friedrich-Naumann-Stiftung für die Freiheit, 2010), h. 26.

14 Adman Nursal, Political Marketing:Strategi Memenangkan Pemilu (Jakarta: Gramedia Pustaka Utama, 2004), h. 55.

${ }^{15}$ Firmanzah, Mengelola Partai Politik; Komunikasi dan Positioning Ideologi Politik Di Era Demokrasi, (Jakarta: Yayasan Obor Indonesia, 2008), h. 10. 
Dalam ranah kampanye, strategi kampanye adalah bentuk khusus dari strategi politik. Tujuannya adalah untuk memperoleh kekuasaan dan pengaruh sebanyak mungkin dengan cara memperoleh hasil yang baik dalam pemilu, agar dapat mendorong kebijakan-kebijakan yang dapat mengarah kepada perubahan masyarakat. Dalam masyarakat demokratis, pengambil-alihan kekuasaan dan peluang untuk merebut pengaruh dilakukan melalui pemilu yang demokratis dalam berbagai bentuk. Tujuannya untuk memperoleh bagian suara yang cukup dalam pasar pemilu. Oleh karenanya, pertempuran untuk memperoleh suara pemilih, yang untuk partai - partai juga merupakan sumber daya yang terbatas harus direncanakan secara hati-hati dan untuk itu diperlukan strategi. ${ }^{16}$

\section{Teori Birokrasi}

Weber memandang bahwa fenomena birokrasi dapat dilihat dalam konteks "teori sosial action" menurut dia semua aktivitas manusia pada dasarnya di gerakkan oleh maksud-maksud tertentu (meanings). Agar supaya kita bisa memahami dan menjelaskan suatu aksi atau aktivitas,maka maksud dan motivasi yang ada di belakang aktifitas itu harus pula di mengerti. ${ }^{17}$

Secara teori, suatu birokrasi mempunyai berbagai sifat yang dapat di bedakan dari ketentuanketentuan lain dari suatu organisasi. Beberapa sifat yang amat penting dapat di kemukakan sebagai berikut; 1.Adanya spesialisasi, atau pembagian kerja; 2.Adanya hirarki yang berkembang; 3.Adanya suatu sistem dari suatu prosedur dan aturan-aturan; 4. Adanya hubungan-hubungan kelompok yang bersifat impersonalitas; 5. Adanya promosi dan jabatan yang berdasrkan atas kecakapan.

Aspek-aspek perilaku yang di cerminkan dari birokrasi Weber dapat di lihat dari penekanan Weber pada struktur yang di timbulkan dari rasa tidak percaya kepada kesanggupan dan kemampuan manusia untuk menciptakan rasionalitas tertentu, mendaptkan informasi yang baik, dan membuat keputusan yang obyektif, premis perilakunya yang Nampak adalah bahwa seseorang itu membutuhkan bantuan untuk sampai kepada pertimbanganpertimbangan yang baik. Struktur adalah jawabanya. Dengan cara spesialisasi prosuder

\footnotetext{
${ }^{16}$ Peter, h. 29

${ }^{17}$ Zainuddin Mustafa, Bunga Rampai Birokrasi (Makassar: Celebes Media Perkasa, 2017), h. 2.
}

aturan-aturan, maka keputusan akan dibuat secara konsisten dan sistematis. ${ }^{18}$

Selama tiga abad, sejak abad kedelapan belas hingga abad kedua puluh, birokrasi di percaya menjadi satu-satunya oraganisasi yang bisa mengatur mekanisme pemerintahan dengan efesien. Bahkan sistem politik diberbagai negara identik dengan birokrasi. Terutama negara-negara yang menganut ideologi sosialisme, atau kelompok negara yang sering disebut sebagai blok timur, kelompok yang kini telah "almarhum" bisa jadi keruntuhan jerman timur yang disusul seluruh blok timur menjadi sinyal paling kuat bahwa kepercayaan akan birokrasi menjadi lentur. Karena birokrasi yang diidealkan oleh Weber ternyata berubah menjadi sebuah monster yang kejam. Istilah birokrasi identik dengan cara kerja sama dengan cara kerja aparatur pemerintah. Artinya, cara kerja aparat pemerintah sendiri sudah di nilai tidak bekerja sebagaimana mestinya. mereka bukan menjadi pelayan masyarakat. Tetapi menjadi "kekuasaan" yang harus di layani oleh masyarakat. ${ }^{19}$

Birokrasi yang di bayangkan Weber sebagai organisasi kemasyarkatan yang superior karena ketepatan, kecepatan dan pengatuhan tentang kerasipan dan kontinuitas, penyimpangan, kesatuan subordinasi yang ketat, pengurangan friksi dan biata material serta personal sulit di temukan dan di praktekkan, karena dua alasan: Birokrasi pada akhirnya harus kawin-kawin dengan budaya setempat yang tidak jarang merupakan revitalitas budaya aristokrasi, entah itu di negara maju maupun di negara berkembang. Tidak heran, karena aristokrasi tetap merupakan "iming-iming" paling menarik bagi setiap manusia. Karena dalam kultur tersebut ia paling mungkin untuk menjadi the ultimate goal. Kedua pada giliranya birokrasi bukan hanya menjadi struktur organisasi sebagai lawan dari organisasi sukarela, ataupun oarganisasi aristokrasi yang di gantikanya melainkan ia menjadi sebuah zat yang "berkuasa", karena mereka bukan hanya "organisasi keamanan " tetapi organisasi yang berisi personel yang m,emegang (monopoli) senjata (pembunuh)." Kekuasaan “" yang di berikan oleh masyarakat kepada birokrasi menjadi bumerang. Karena ada Satu hal yang di lupakan, bahwa sebagai sistem birokrasi pun perlu untuk mengalami self renewal. ${ }^{20}$

\footnotetext{
${ }^{18}$ Zainuddin, h. 3.

${ }^{19}$ Zainuddin, h. 6.

${ }^{20}$ Zainuddin, h. 7 .
} 


\section{METODE PENELITIAN}

Penelitian ini dilaksanakan di Kabupaten Maros dalam kurung waktu bulan Desember 2017 sampai Maret 2018. Jenis penelitian yang digunakan adalah penelitian kualitatif deskriptif dan data yang dikumpulkan melalui observasi, wawancara dan kajian literatur. $^{21}$

Penelitian ini berfokus pada kekuatan politik birokrasi terhadap kemenangan incumbent dengan mendeskripsikan bentuk kekuatan yang mendukung secara signifikan kemenangan Hatta Rahman di Pilkada Kab. Maros tahun 2015. Beberapa analisis yang dilakukan adalah dengan menjelaskan jaringan politik Hatta Rahman, bentuk kekuatan birokrasi, kekuatan partai pendukung.

\section{PEMBAHASAN}

\section{Mengenal Sosok Hatta Rahman}

Ir. H. M. Hatta Rahman, MM. lahir di Maros, 09 September 1966. Hatta Rahman memiliki istri yang bernama Hj. Suraida Hatta. Hatta Rahman saat ini menjabat sebagai Bupati Maros (2010-2015) yang dipilih secara langsung. Sebelum menjabat sebagai Bupati, Hatta Rahman pernah menjabat sebagai Ketua DPD Partai Amanat Nasional Maros, Tahun 2002 - sekarang dan Hatta Rahman merupakan calon incumbent pada pilkada Bupati Maros pada tahun 2015 lalu. Hatta Rahman juga pernah berkecimpung dibeberapa organisasi dengan posisi yang strategis, yaitu Ketua HIPMI (Himpunan Pengusaha Muda Indonesia), Ketua Kharisma Kawula Muda Maros (KKMM), dan beberapa organisasi lainnya, sebelum akhirya terpilih sebagai Bupati Kabupaten Maros periode 2010-2015.

Pada Pilkada Maros tahun 2015 Hatta Rahman berpasangan dengan $\mathrm{H}$. A. Harmil Mattotorang yang pernah menjabat sebagai Kabag Keuangan Pemkab Maros. Pasangan tersebut diusung oleh koalisi Partai Amanat Nasional (PAN) ditambah sejumlah partai kecil lainnya.

\section{Daftar Partai Pengusung}

\begin{tabular}{|c|l|c|}
\hline No. & \multicolumn{1}{|c|}{ Partai Politik } & Kursi DPRD \\
\hline 1. & Partai Amanat Nasional & 9 \\
\hline 2. & Partai NasDem & 3 \\
\hline 3. & Partai kebangkitan Bangsa & 1 \\
\hline 4. & PDI-Perjuangan & 1 \\
\hline
\end{tabular}

21 Syamsuddin, dkk., Pedoman Praktis Metodologi Penelitian Internal,(Ponorogo: CV. Wade Group, 2015), h. 19.

\begin{tabular}{|c|c|}
\hline Total & $\mathbf{1 4}$ \\
\hline Sumber: Diolah penulis dari Tim Sukses Hatita
\end{tabular}

Setelah menjalani persaingan yang ketat, Hatta Rahman akhirnya memenangi pemilihan Bupati untuk periode keduanya bersama pasangannya, $\mathrm{H}$. A. Harmil Mattotorang. Bupati yang terkenal dengan tagline "Hatita" ini mulai merealisasikan ide-idenya, antara lain Maros Lebih Sejahtera 2021. Adapun visi Hatta Rahman di jabarkan dalam enam poin misi, yaitu meningkatkan perekonomian daerah, meningkatkan kualitas pelayanan publik, meningkatkan kualitas hidup masyarakat, meningkatkan pembangunan wilayah dan kawasan, meningkatkan kualitas pengelolaan sumber daya alam, serta meningkatkan pem bangunan infarastruktur dan teknologi.

Melihat sepak terjang Hatta Rahman dalam ranah politik sudah bisa dikatakan bahwa beliau mampu menjadi pemimpin, terbukti dari beberapa organisasi yang digelutinya didukung pengalaman kerja yang sudah tidak di ragukan lagi, dan pandangan masyarakat Maros mengatakan bahwa sosok Hatta Rahman sangat ramah terhadap masyarakat. Hatta Rahman mempunyai modal sosial karena beliau merupakan sosok yang paling dikenal masyarakat lokal sebagai calon Bupati Maros yang pernah menjabat sebelumnya.

Sebagai petahana, Hatta Rahman tak perlu lagi memperkenalkan diri kepada masyarakat Kabupaten Maros. Meskipun demikian, tetap penting untuk melakukan sosialisasi di masyarakat untuk memperbesar tingkat keterpilihannya. Hal tersebut jelas berbeda dengan kandidat yang lain, sebab untuk membuat dirinya dikenal oleh masyarakat, maka kandidat lain dituntut untuk melakukan sosialisasi personal yang besar dan intens.

Persentase suara yang dimiliki pasangan Hatta Rahman dan Harmil Mattotorang memiliki persentase teritinggi dibanding kandidat lainnya dengan persentase $67,63 \%$ atau 106.942 suara. disusul oleh Husain Rasul dan Sudirman Sirajuddin dengan persentase $29.69 \%$ atau 46.945 suara, lalu kandidat H. Muh. Imran yusuf dan Said Patombongi dengan persentase $2.67 \%$ atau 4.229 suara.

Tingkat presentase yang dominan dari perolehan suara politiknya mengindikasikan Hatta Rahman cukup dikenal luas dan diterima masyarakat Maros. Masyarakat mengenal Hatta Rahman sebagai 
seorang yang pernah berkontribusi untuk kepentingan masyarakat, meskipun kontribusi untuk kepentingan masyarakat tersebut masih dapat diperdebatkan terutama seberapa besar kebijakan dan program yang diimplementasikannya berdampak pada masyarakat. Faktor lainnya adalah figur Hatta Rahman sebagai seorang calon yang berstatus incumbent memiliki sumber daya yang cukup besar, materi, sebagai akumulasi dari kepemimpinannya selama ini. Selain itu Hatta Rahman memiliki jaringan yang cukup luas di kalangan elite dan masyarakat local. Oleh Karena itu, Hatta Rahman memiliki peluang yang besar untuk mengoptimalkan sumber daya tersebut.

Peran dari partai pendukung juga merupakan hal yang menunjang kemenangan Hatta rahman pada Pilkada Kab. Maros tahun 2015, sebab selain sebagai Bupati Maros, Ia juga menjabat sebagai ketua DPC Partai Amanat Nasional Kab. Maros. Melalui kendaraan politik inilah salah satu hal penunjang kemenangan Hatta Rahman. Selain itu, Harmin Mattotorang yang merupakan pasangan wakil Hatta Rahman juga merupakan ketua DPC Nasdem, tentunya hal ini semakin memperkuat gerak politik mereka, sebab keduanya adalah pimpinan partai di Kab. Maros. Relasi dukungan dari partai politik ini merupakan penyokong kemenangan Hatta Rahman.

Partai Politik merupakan salah satu kekuatan penting yang turut mendukung kemenangan Hatta Rahman pada Pilkada Maros tahun 2015 ialah keterlibatan jajaran pegawai negeri di Kab. Maros. Struktur birokrasi yang merupakan konstruk kepemimpinan Hatta Rahman membuat mereka harus memilih Hatta Rahman meskipun tidak nampak namun dapat dikatakan bahwa andil birokrasi juga turut memberikan signifikansi suara bagi Hatta Rahman. Selama menjabat periode sebelumnya Hatta Rahman memang mengarahkan salah satu fokusnya pada penataan yang efektif bagi kerjakerja birokrasi sehingga menciptakan pelayanan yang baik. Program yang mengarah pada birokrasi ini, kemudian menjadi senjata yang secara langsung maupun tidak langsung menjadi penopang suara dari kalangan birokrasi, terlepas mereka mengamankan posisi mereka.

Kepemimpinan Hatta Rahman selama menjabar sebagai Bupati Maros dapat dikatakan berhasil menyinkronisasikan birokrasi hingga efektif. . Oleh karenanya, suara Hatta Rahman juga tergerak dari tatanan birokrasi. Kekuatan birokrasi yang menyokong kemenangan Hatta Rahman dapat dikatakan besar, karena pengaruh kekuasaan Hatta Rahman.

\section{Bentuk Kekuatan Politik Birokrasi}

Salah satu strategi politik yang dilakukan incumbent untuk melanggengkan kekuasaannya adalah dengan memanfaatkan kekuatan birokrasi. Strategi politik dengan memanfaatkan birokrasi merupakan strategi yang cukup efektif untuk memenangkan kontestasi politik Pilkada. Penguasaan politik jaringan pemerintahan terfokus pada pengkondisian birokrasi di lingkungan pemerintah daerah Kabupaten Maros. Mengingat Hatta Rahman adalah seorang incunmbent maka dapat saja memerintahkan bawahannya untuk memilih dirinya. Jaringan yang telah dibangun Hatta Rahman dapat memengaruhi birokrasi yang ada di Kabupaten Maros mulai dari tingkal level instansi terbawah sampai teratas untuk memilihnya, sehingga kondisi ini memudahkan Hatta Rahman.

Kemenangan Hatta Rahman pada Pilkada Serentak tahun 2015 tidak dapat dilepaskan dari peran birokrasi. Berikut beberapa bentuk kekuatan politik birokrasi dalam mendukung kemenangan Hatta Rahman tersebut.

\section{Jaringan yang Luas dan Sistem Organisasi yang Masif}

Birokrasi memiliki sistem organisasi yang kuat dan terstruktur. Hal tersebut merupakan salah satu keunggulan yang dimiliki oleh birokrasi disbanding kan organisasi-organisasi lain. Setiap pegawai dituntut untuk loyal terhadap atasannya sehingga pola-pola patrimonial bekerja cukup kuat dalam sistem birokrasi. Pola-pola patrimonial yang masih kuat memberikan keuntungan kepada pimpinan tertinggi dalam struktur birokrasi.

Di tingkat lokal, Kepala Daerah memegang kendali atau berada pada pucuk tertinggi dalam struktur kekuasaan birokrasi. Dalam hierarkhi kekuasaan birokrasi, Kepala Daerah berperan sebagai penanggungjawab dan pembuat keputusan. Pada konteks Pemerintahan Kabupaten Maros, Hatta Rahman selaku Bupati Maros merupakan pimpinan tertinggi birokrasi pada tataran wilayah Kabupaten Maros. Sehingga birokrasi berperan sebagai aparatur yang mengejewantahkan berbagai instruksi dan perintah langsung dari Hatta Rahman.

Sistem organisasi yang utuh dan terstruktur merupakan kelebihan yang dimiliki oleh birokrasi. Hierarkhi kekuasaan pada birokrasi menyebabkan 
kekuasaan bekerja secara struktural, sesuai dengan instruksi dan kepentingan dari pimpinan. Pada tataran lingkungan Kabupaten Maros, Hatta Rahman selaku Bupati memiliki kendali besar terhadap kinerja dari birokrasi di wilayah Maros. Secara tidak langsung birokrasi dapat dimanfaatkan untuk mendukung kepentingan-kepentingan Hatta Rahman khususnya kepentingan-kepentingan politiknya.

Posisi Hatta Rahman selaku calon incumbent dapat dengan mudah mempengaruhi dan memobilisasi dukungan politik dari kalangan birokrat. Sebab di satu sisi karakteristik birokrasi yang dituntut loyal kepada atasannya maka secara tidak langsung akan mendukung kepentingan-kepentingan politik dari atasannya tersebut. Di sisi yang lain posisi-posisi para birokrat (pejabat) pada strutur kekuasaan menyebabkan mereka berorientasi untuk mengamankan posisi yang mereka miliki dengan mendukung calon incumbent, sebab jika incumbent dikalahkan maka boleh jadi posisi mereka akan terancam atau digantikan dengan birokrat yang lain. Sehingga hal ini diantisipasi oleh para petinggi ditataran struktural birokrasi. Salah satu strategi yang umum dilakukan para incumbent mempengaruhi dan memperoleh dukungan politik dari kalangan birokrasi adalah melalui komersialisasi jabatan.

Di lingkup birokrasi Maros, pengamanan posisi jabatan menjadi salah satu bentuk timbal balik politik setelah memilih incumbent, sebab pada dasarnya rotasi kemepimpinan disuatu daerah dapat juga merubah tatanan jajaran pejabat pegawai negeri. Oleh karena itu, banyak PNS yang tetap mendukung Hatta Rahman demi menjaga posisi jabatannya agar tidak tergeser oleh orang lain. Berikut hasil wawancara dengan Camat Mandai menjelaskan mengenai:

"Meskipun saya baru sebentar menjabat menggantikan Camat lalu yang terkena kasus, namun saya memilih Pak Hatta Rahman, ini sebuah kepercayaan bagi saya dan juga kinerja Pak Hata Rahman terbilang baik membangun tatanan birokrasi di Maros, dan saya mendukung beliau. ${ }^{, 22}$

Wawancara ini secara tidak langsung dapat diinterpretasikan sebagai sebuah hal yang mengandung unsur politisasi jabatan. Menjaga

\footnotetext{
22 Andi Mappalewa (Camat Mandai), wawancara pada tanggal 8 Januari 2018.
}

posisi jabatan perseorangan menjadi alasan keberpihakan kepada Hatta Rahman, oleh karena itu banyak PNS yang memilih Hatta Rahman. Hal inilah yang menjadi salah satu basis kekuatan Hatta Rahman untuk melanggengkan kemenangannya di kontestasi politik Kab. Maros.

Jumlah birokrasi yang cukup besar didukung oleh loyalitas mereka merupakan salah satu kekuatan politik yang besar yang dimanfaatkan oleh Hatta Rahman selaku calon incumbent untuk memenangkan Pilkada Maros tahun 2015.

\section{Akses terhadap Penguasaan Sumber Daya}

Birokrasi adalah organisasi yang menjadi instrumen penyelenggaraan berbagai pelayanan publik, oleh karena itu birokrasi memiliki akses terhadap penguasaan sumber daya. Penguasaan terhadap sumber daya merupakan salah satu kekuatan penting yang dimiliki oleh birokrasi. Ketidaknetralan birokrasi dapat berujung pada pemanfaatan berbagai sumber daya diantaranya anggaran negara dan fasilitas negara untuk kepentingan pragmatis dari pihak-pihak tertentu.

Netralitas birokrasi pada setiap momentum kontestasi kekuasaan selalu menjadi permasalahan yang umum terjadi. Birokrasi adalah kelompok yang sangat rawan untuk disalahgunakan oleh eliteelite politik untuk kepentingan politik pragmatis, khususnya bagi incumbent. Incumbent memiliki pengaruh besar terhadap birokrasi. Para incumbent berusaha mengonsolidasikan organisasi birokrasi untuk memenangkan mereka pada pemilu.

Suara pegawai negeri menjadi salah satu modal yang menjanjikan pada setiap momen-momen pemilu, begitupun di ranah politik Kab. Maros. Berikut wawancara dengan Anggota DPRD Kab. Maros Bpk. Andi Syahril:

"Ada beberapa pegawai yang mendukung hatta rahman baik itu dari kalangan PNS, ataupun instansi masyarakat yang mengaku mendukung seorang Hatta Rahman, dengan alasan hampir rata-rata mengatakan bahwa kinerja seorang bapak Hatta Rahman sudah terakui dengan banyaknya infarastruktur jalan yang sudah baik. "23

Hal tersebut juga diperkuat oleh informasi dari portal berita online berikut ini:

\footnotetext{
23 Andi Syahrir (Anggota DPRD Fraksi Nasdem), wawancara pada tanggal 25 Desember 2017.
} 


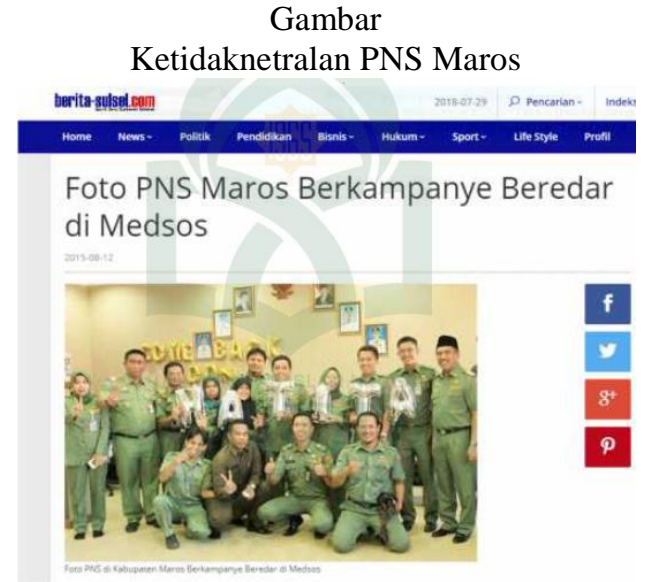

Sumber: berita-sulsel.com

Foto sejumlah Pegawai Negeri Sipil (PNS) lengkap dengan pakaian dinasnya yang menenteng simbol salah satu kandidat Bupati dan wakil Bupati Maros beredar luas melalui jejaring media sosial. Gambar yang diperkirakan direkam di ruang kerja mantan Bupati Maros, Hatta Rahman ini, begitu tampak jelas memperlihatkan belasan PNS ini mengacungkan dua jari mereka sebagai simbol pasangan Hatta Rahman dan Harmil Mattotorang (Hatita) jilid dua. ${ }^{24}$

Hal di atas dapat di artikan bahwa, tidak sepenuhnya apa yang dilakukan Hatta Rahman dalam proses kemenangannya diraih dengan modalnya. Tidak bisa di pungkiri bahwa kuasa incumbent secara langsung maupun tidak langsung dapat dengan mudah menggerakkan apapun dalam proses perpolitikan. Penggunaan fasilitas daerah secara mungkin memudahkan akses kampanyenya dan mengurangi anggaran biaya yang di butuhkan.

\section{Instrumen Komunikasi Pemerintah}

Dalam teori komunikasi, setiap aktor membutuh kan ruang komunikasi yang efektif untuk menyampaikan pesan-pesan mereka kepada komunikan atau penerima pesan. Birokrasi dapat menjadi media komunikasi yang efektif bagi calon incumbent untuk berkomunikasi dengan masyarakat. Sebab birokrasi dapat bersentuhan langsung dengan masyarakat melalui pelayananpelayanan publik. Hal tersebut dapat dimanfaatkan sebagai ruang politik bagi para calon incumbent untuk menarik simpati masyarakat. Sehingga

${ }^{24}$ Admin, "Foto PNS Maros Berkampanye Beredar di Medsos," Berita-Sulsel.com. 12 Agustus 2018.http://beritasulsel.com/2015/08/12/foto-pns-maros-berkampanye-beredardi-medsos/(4 Maret 2018). birokrasi tidak hanya sebagai instrument bagi negara untuk memberikan pelayanan kepada masyarakat melainkan juga menjadi instrument politik bagi para calon incumbent untuk menarik simpati dan dukungan dari masyarakat luas.

Birokrasi merupakan instrumen bagi pemerintah untuk berkomunikasi secara langsung dengan masyarakat. Komunikasi tersebut dapat terjalin diantaranya melalui proses penyelenggaraan pelayanan publik. Baik buruknya pelayanan publik yang diberikan oleh birokrasi sangat terkait dengan kemampuan dan kualitas dari birokrasi itu sendiri. Kemampuan birokrat pemerintahan selain dibentuk melalui pengembangan dan peningkatan pengetahuan dan keahlian individu juga sangat di pengaruhi oleh sistem organisasi tersebut seperti orientasi kerja, struktur organisasi, model kepemimpinan yang diterima oleh aparatur.

Peran pemerintah seharusnya yang selama ini sebagai ruler seharusnya di ganti dengan sebagai fasilitator dengan demikian menempatkan paradigma baru dengan menempatkan birokrasi sebagai fasilitator bukan sebagai ruler atau patron. Namun untuk mewujudkan cita-cita tersebut tetap harus diupayakan demi memberikan pelayanan yang baik kepada publik dan mampu memperbaiki citra birokrasi yang selama ini dianggap gagal sebagai media perantara masyarakat.

Bekerjanya birokrasi yang baik dapat meningkat kan kepercayaan masyarakat. Hatta Rahman melakukan ini dalam menata Maros yang lebih sejahtera sehingga masyarakat Maros melihat proses kinerja birokrasi yang tertata rapi, dengan begitu citra seorang Hatta Rahman sangat baik. Salah satu contoh pembuatan KTP yang dulu begitu lama proses pembuatanya, dan sekarang dengan sistem dan kinerja aparatur yang baik proses pembuatan KTP dapat dengan mudah dan cepat pelayanannya, dan bukan hanya itu masyarakat tingkat bawah dapat merasakan bagaimana dalam perumusan perumusan masalahmasalah di internal desa dapat menyuarakan haknya, rapat-rapat internal dikantor desa, seperti yang diungkapkan salah seorang warga di Pattene Burhanuddin.

"Saya biasa ikut rapat dalam Kantor Lurah dan menyuarakan hak saya sebagai masyarakat, seperti permintaan perbaikan jalan dan infastruktur lainya 
dan Alhamdulillah bisa kita lihat hasilnya jalanjalan sudah di perbaiki. "25

\section{Pelaksana Kebijakan Publik}

Birokrasi merupakan salah satu badan yang paling sering bahkan secara keseluruhan menjadi pelaksana kebijakan. Birokrasi baik secara sadar atau tidak sadar memilih bentuk-bentuk organisasi untuk kesepakatan kolektif, dalam rangka memecahkan masalah-masalah sosial dalam kehidupan modern. Mereka tidak hanya berada dalam struktur pemerintah, tetapi juga berada dalam organisasi-organisasi swasta yang lain bahkan di institusi-institusi pendidikan dan kadangkala suatu sistem birokrasi sengaja diciptakan untuk menjalankan suatu kebijakan tertentu. ${ }^{26}$

Birokrasi merupakan instrumen yang mengejawantahan kebijakan dari pemerintah. Sebagai instrumen pengejewantahan kebijakan publik, birokrasi memiliki kelebihan-kelebihan diantaranya penguasaan atas sumber daya dan akses langsung di masyarakat. Hal tersebut menjadi salah satu kekuatan politik cukup penting yang dimiliki birokrasi. Sebagai instrumen yang menjalankan kebijakankebijakan publik maka masyarakat memiliki ketergantungan dengan birokrasi untuk memperoleh hak-haknya khususnya sebagai warga negara, diantaranya memperoleh pelayanan kesehatan ataupun administrasi. Pelayan yang dilakukan oleh birokrasi juga dapat dinilai oleh masyarakat. Dalam hal ini kinerja birokrasi yang baik dapat berdampak positif pada penilaian masyarakat terhadap kinerja Hatta Rahman selaku Bupati Maros pada periode sebelumnya. Hal ini sebagaimana hasil wawancara dengan salah seorang informan berikut ini:

"Program-program yang di lakukan seorang Bapak Hatta Rahman sudah bisa dikatakan baik karena dalam proses pengurusan misalnya pengrusan KTP,BPJS tidak serumit dulu. artinya sekarang proses mengurus di kantor desa ataupun kantor camat sudah cepat dan di layani dengan baik". ${ }^{27}$

25 Burhanuddin (Warga), wawancara pada tanggal 3 Februari 2018.

${ }^{26}$ Budi Winarno, Kebijakan Publik: Teori dan Proses (Yogyakarta: MedPress, 2007), h. 202.

27 Kamaruddin (Masyarakat Mandai), wawancara pada tanggal 25 Desember 2017.
Kemenangan Hatta Rahman pada Pilkada Maros tahun 2015, tidak dapat dilepaskan dari kinerja dari aparat birokrasi pemerintah Kab. Maros dalam menyelenggarakan pelayan publik di masyarakat. Melalui pelayanan publik, Hatta Rahman selaku calon incumbent menarik simpati dan dukungan masyarakat Kab. Maros melalui efektivitas dan baiknya pelayanan yang dilakukan oleh aparat birokrasi.

\section{Representasi Kepemimpinan Politik}

Birokrasi pada dasarnya merupakan cerminan kepemimpinan politik. Efektivitas dan manajemen birokrasi yang baik dapat berdampak pada terimplementasinya kebijakan dengan baik. Sebaliknya kinerja birokrasi yang buruk akan berujung pada buruknya kinerja pemerintah di mata masyarakat. Kinerja birokrasi yang baik akan megonstruksi keberhasilan kepemimpinan politik dari elite politik. Sebaliknya semerawutnya manajemen birokrasi dapat berdampak pada citra buruk dari kepemimpinan elite politik.

Terciptanya birokrasi yang baik sangat tergantung bagamana pemimpin yang ada dalam daerah tersebut, ibarat pepatah jika guru kencing berdiri maka murid kencing berlari artinya seorang pemimpin harus memberikan contoh yang baik agar yang dipimpinnya juga menjadi baik. Efektivitas kinerja birokrasi yang dianggap cukup baik oleh masyarakat merepresentasikan kepemimpinan Hatta Rahma selaku Bupati Maros yang dianggap cukup berhasil. Hal tersebut mendongkrak popularitas dari Hatta Rahman sehingga dapat terpilih kembali pada periode keduanya.

Kepercayaan masyarakat kepada sosok Hatta Rahman untuk memimpin Kab. Maros sudah terakui dengan program-program yang berhasil diwujudkannya pada periode sebelumnya, diantaranya perbaikan infrastruktur. Programprogram tersebut diimplementasikan dengan baik oleh aparat birokrasi di bawah kepemimpinan Hatta Rahman.

\section{PENUTUP}

Berdasarkan penelitian yang telah dilakukan mengenai bentuk kekuatan politik Hatta Rahman terhadap birokrasi di Kabupaten Maros pada Pilkada tahun 2015, diperoleh hasil yang mempengaruhi keterpilihan Hatta Rahman di panggung politik Kab. Maros, disamping karena jaringan sosial yang kuat dan didukung oleh partai 
politik, juga dipengaruhi oleh akses yang besar untuk memperoleh dukungan dari kalangan birokrasi di Kab. Maros.

Salah satu strategi politik yang dilakukan incumbent untuk melanggengkan kekuasaannya adalah dengan memanfaatkan kekuatan birokrasi. Strategi politik dengan memanfaatkan birokrasi merupakan strategi yang cukup efektif untuk memenangkan kontestasi politik Pilkada.

Adapun beberapa bentuk kekuatan politik birokrasi dalam mendukung kemenangan Hatta Rahman tersebut antara lain; jaringan yang luas dan sistem organisasi yang masif, akses terhadap penguasaan sumber daya, instrumen komunikasi pemerintah, pelaksana kebijakan publik, dan representasi kepemimpinan politik.

Birokrasi memiliki sistem organisasi yang kuat dan terstruktur. Setiap pegawai dituntut untuk loyal terhadap atasannya sehingga pola-pola patrimonial bekerja cukup kuat dalam sistem birokrasi. Posisi Hatta Rahman selaku calon incumbent dapat dengan mudah mempengaruhi dan memobilisasi dukungan politik dari kalangan birokrat. Penguasaan terhadap sumber daya merupakan juga merupakan salah satu kekuatan penting yang dimiliki oleh birokrasi.

Birokrasi dapat menjadi media komunikasi yang efektif bagi calon incumbent untuk berkomunikasi dengan masyarakat. Hal ini juga yang dilakukan oleh Hatta Rahman. Melalui pelayanan dan peningkatan kinerja birokrasi di Kab. Maros yang diupayakan oleh Hatta Rahman maka berdampak pada tingginya simpati dan dukungan politik masyarakat luas di Kab. Maros kepada Hatta Rahman.

Birokrasi merupakan instrumen yang mengejawantahan kebijakan dari pemerintah serta merupakan cerminan dari kepemimpinan politik. Kinerja birokrasi yang baik akan menkonstruksi keberhasilan kepemimpinan politik dari elite politik. Sebaliknya semrawutnya manajemen birokrasi dapat berdampak pada citra buruk dari kepemimpinan elite politik.

Implikasinya, keterlibatan dalam politik adalah hak dari setiap warga negara, namun sebagai Aparatur Sipil Negara, birokrasi harus menghindari keterlibatan pada politik praktis, termasuk mendukung kepentingan-kepentingan politik pragmatis dari pimpinan mereka dalam struktrur birokrasi sehingga dapat berujung pada maksimalisasi peran dan fungsi mereka pada pelayanan publik yang efektif.

$* * *$

\section{DAFTAR PUSTAKA}

Adman Nursal, Political Marketing:Strategi Memenangkan Pemilu (Jakarta: Gramedia Pustaka Utama, 2004).

Ajeng Niadharma, "Strategi Pemasaran Politik Pasangan Sambari-Qosim Dalam PemilihanKepala Daerah Gresik Tahun 2015", Jurnal Politik Muda,Vol. 5, Nomor 3, (Agustus-Desember 2016).

Alexander Irwan, Pemilu Pelanggaran Asas Luber, (Jakarta : Pustaka Sinar Harapan, 1996).

Ayub Liwang, "Kekuatan dan Stretegi Politik Dalam Pemilukada, Analisis Kemenangan Adnan Puricta dalam Pilkada Kab. Gowa tahun 2015", Skripsi, (Makassar: Jurusan Ilmu Politik, Fakultas Ushuluddin, Filsafat dan Ilmu Politik, UIN Alauddin, 2015).

Budi Winarno, Kebijakan Publik: Teori dan Proses (Yogyakarta: MedPress, 2007).

Cholisin dan Nasiwan, Dasar-Dasar Ilmu Politik (Yogyakarta: Penerbit Ombak, 2012).

Dian Rhesa Rahmayanti, "Pemasaran Politik (Political Marketing) Partai Golongan Karya Dan Partai Demokrat. (Studi Tentang Perbandingan Pemasaran Politik Partai Golkar Dan Partai Demokrat Dalam Rangka Menarik Massa Pada Pemilihan Umum Legislatif Tahun 2009 Di Daerah Pilihan II Kabupaten Madiun", Skripsi (Surakarta: Fakultas Ilmu Sosial dan Ilmu Politik Universitas Sebelas Maret Surakarta, 2009).

Firmanzah, Mengelola Partai Politik; Komunikasi dan Positioning Ideologi Politik Di Era Demokrasi, (Jakarta: Yayasan Obor Indonesia, 2008).

Hartini Basaria Natasya Sitanggang dan Awang Dharmawan, "Strategi Marketing Hary Tanoesoedibjo dalam Usaha Membangun Personal Branding Politik", Jurnal Penelitian Pers dan Komunikasi Pembangunan, Vol. 20 No.1 (Juni 2016). 
Joel Migdal, Strong Societies and Weak States: State Society Relation and State Capabilities in the Third World. (Princeton: Princeton University Press, 1988).

Leo Agustino, Politik Lokal dan Otonomi Daerah, (Bandung: Alfabeta, 2014).

Peter Schröder, Strategi Politik, Cet. Tiga (Jakarta: Friedrich-Naumann-Stiftung für die Freiheit, 2010).

Syamsuddin, dkk., Pedoman Praktis Metodologi Penelitian Internal,(Ponorogo: CV. Wade Group, 2015).

Umaimah Wahid "Personal Brandingdan Retorika Komunikator Politik Pada Pemilukada DKI Jakarta 2017 (Analisis Retorika Atas Teks Pidato Sebagai Kandidat Gubernur Dan Wakil Gubernur Pada Penentuan Nomor Urut Peserta Pemilu)", Prosiding Seminar Nasional : Komunikasi Publik dan Dinamika Masyarakat Lokal (Lampung: Magister Ilmu Komunikasi, Universitas Lampung, 2016).

Zainuddin Mustafa, Bunga Rampai Birokrasi (Makassar: Celebes Media Perkasa, 2017).

\section{Wawancara}

Andi Mappalewa (Camat Mandai), wawancara pada tanggal 8 Januari 2018.

Andi Syahrir (Anggota DPRD Fraksi Nasdem), wawancara pada tanggal 25 Desember 2017.

Burhanuddin (Warga), wawancara pada tanggal 3 Februari 2018.

Kamaruddin (Warga), wawancara pada tanggal 25 Desember 2017.

\section{Website}

Admin, "Foto PNS Maros Berkampanye Beredar di Medsos," Berita-Sulsel.com. 12 Agustus 2018.http://berita-sulsel.com/2015/08/12/fotopns-maros-berkampanye-beredar-dimedsos/(4 Maret 2018). 